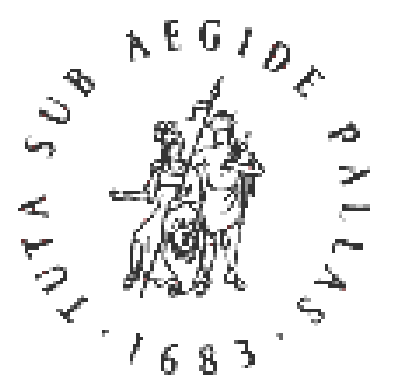

B R I L L

Ndembu, Luunda and Yaka Divination Compared: From Representation and Social Engineering to Embodiment and Worldmaking Author(s): Filip de Boeck and René Devisch

Source: Journal of Religion in Africa, Vol. 24, Fasc. 2 (May, 1994), pp. 98-133

Published by: BRILL

Stable URL: http://www.jstor.org/stable/1581328

Accessed: $13 / 08 / 2010$ 08:55

Your use of the JSTOR archive indicates your acceptance of JSTOR's Terms and Conditions of Use, available at http://www.jstor.org/page/info/about/policies/terms.jsp. JSTOR's Terms and Conditions of Use provides, in part, that unless you have obtained prior permission, you may not download an entire issue of a journal or multiple copies of articles, and you may use content in the JSTOR archive only for your personal, non-commercial use.

Please contact the publisher regarding any further use of this work. Publisher contact information may be obtained at http://www.jstor.org/action/showPublisher?publisherCode=bap.

Each copy of any part of a JSTOR transmission must contain the same copyright notice that appears on the screen or printed page of such transmission.

JSTOR is a not-for-profit service that helps scholars, researchers, and students discover, use, and build upon a wide range of content in a trusted digital archive. We use information technology and tools to increase productivity and facilitate new forms of scholarship. For more information about JSTOR, please contact support@ jstor.org. 


\title{
NDEMBU, LUUNDA AND YAKA DIVINATION COMPARED: FROM REPRESENTATION AND SOCIAL ENGINEERING TO EMBODIMENT AND WORLDMAKING
}

\author{
BY \\ FILIP DE BOECK \& RENÉ DEVISCH \\ (The University of Leuven, Belgium)
}

Victor Turner's superb ethnography, his virtuoso symbolic analysis, and innovative theoretical developments, have inspired thought-provoking perspectives in the approach to ritual action and social drama in many areas of cultural analysis, whether it be anthropology, the history of religion, literature, or theatre (cf Ashley 1990; Deflem 1991; Moore and Reynolds 1984). That we are capable of engaging in an intergenerational dialogue, or trialogue-to paraphrase James Clifford (1988)-and of comparing our own field data to his own, is a tribute to Turner the ethnographer, and bears witness to the solidness of his Ndembu data.

This study deals with the Ndembu of northern Zambia, and the neighbouring Luunda and Yaka of the Kwaango in southwestern Zaire. Ndembu and Yaka peoples owe a great deal of their ritual institutions to the Luunda. About three centuries ago, Luunda groups left the Ruund nucleus in what is now the Zairean province of Shaba, and started to migrate westwards: some settled in the Upper-Kwaango, while others migrated further northwards to impose centralising political institutions onto Yaka people. The Ndembu issue from a southern migration wave out of the same Ruund core. Drawing upon our respective field research among Luunda and $\mathrm{Yaka}^{1}$, we will present a critical evaluation of Turner's views on Ndembu ritual from a comparative perspective. We will focus on his approach to Ndembu basket divination, ngombu yakusekula (Turner 1961, 1968, 1975).

In a first part, we will discuss Turner's cognitivist stress in his presentation of the way in which ritual, symbols, and metaphors 
operate through their multidimensional meanings in social drama and, in particular, in divination. Drawing on Luunda and Yaka data on divination, we will point out some of the shortcomings and biases of Turner's view on (divinatory) ritual, and present alternative approaches. ${ }^{2}$ It will be argued that a one-sided emphasis on the pragmatics of social transformation by means of symbols as arguments, combined with a cognitive reading of symbolic meaning, brings out only part of what happens in a ritual. We would argue that Turner sees the participants' position in a ritual as somewhat similar to his own external, though tender, look as ethnographer. Although he acknowledges people's sensory involvement and sharing of affects and values in rituals, participants mainly enact these as social role players, who thereby come to represent in social life what they reenact in the ritual. Symbols move actors, correct deflections and deviations, resolve social contradictions, and wed actors to the categories and norms of their society. By privileging the symbolic meanings that are grasped by people, and actuating appropriate social action, Turner reduces the ritual to a script or text for society; ritual becomes 'an orchestration of many genres, styles, moods, atmospheres, tempi, and so on' (Turner 1977:40).

Secondly, we will compare divination among Ndembu, Luunda and Yaka. With regard to basket divination, Turner's views imply that the diviner and consultants consider the objects in the diviner's basket as icons or mnemonic devices in their search for the what, the who and the why of the social problem at hand. Divinatory objects provide an analogical text or a script that outlines political structure and the potent force of kinship; a script that can be read, interpreted, reflexively captured and narrated by the diviner. For Turner, in other words, the hidden script of divination is the social drama, and the divinatory symbols are storage units filled with information, moods, and values that allow for the proper representation and rearrangement of, and involvement with, the interactional plot in a group.

With our comparison of Ndembu, Luunda and Yaka divination, we intend to show how much divination goes beyond the interactional setting of the consultation, the (textual representation of the) social drama, and the purpose of social engineering. Seen in its own terms, divination does not so much offer a mimetic model of a social context, but rather makes a world. We argue that Turner 
overlooks this more demiurgic capacity of divination as a mode of worldmaking. In our opinion, the signification visually displayed in the mnemonic images or divinatory objects in the basket is more complex and more difficult to grasp and communicate than verbal semantic meaning. In their iconic expressiveness, these images outreach the semantic assertions and categorical knowledge associated with their display and manipulation. More importantly, however, their use also involves a different experience of knowing, remembering and interpreting. We contend that the basket divination eludes an interpretation that foregrounds an epistemology which focuses exclusively on the highly representational mode of textuality alone. Basket divination offers more than a stage for the identification and the compelling manifestation of cognitive structures; as interactional and highly sensory performance, it constitutes a space in which cognitive structures are transformed and new relations are generated in and between the fields of the human body (senses, emotions), the social body and the cosmos. In analysing divination as an open-ended, processual mode of transformation and meaning-making, our focus is on agency as a practice of meaning and empowerment.

\section{The meaning of Turner's 'meaning'}

In The Drums of Affliction Turner opens the chapter on divinatory symbolism by demonstrating 'how readily and explicitly diviners are able to offer interpretations of their symbols' (Turner 1968:29; 1975:211). In fact, Turner's writings were strongly innovative in reenacting the 'speaking subject' (cf. Jules-Rosette's notion of 'decentering' in this issue)-a phenomenological dimension of his approach that builds up an ethnography from what participants say about what they do in the ritual, why, and what this all represents to them. The possibility of exegetical knowledge and explanation links in with Turner's notion of the 'meaning' of a symbol, and the way this meaning can be captured by the anthropologist. According to Turner, symbolic meaning can be obtained in three interrelated ways: first of all, on the level of exegetical meaning, from questioning indigenous informants about observed ritual behaviour. The exegetical level can either be esoteric or exoteric, depending upon whether the information is given by ritual specialists or laymen. The second level Turner distinguishes is that of operational mean- 
ing, obtained through the observation of the ways symbols are used in ritual. Symbols, in Turner's approach, are above all to be observed when ritually performed. Concerned with the efficacy of symbols, he analyzes how ritual works, what it does, and how people handle symbols. Symbols are thus primarily studies for their action-meaning in their significant social or action field, as well as their cultural field of beliefs, rituals and religion. Third is the level of positional meaning, which is obtained from investigating the relationship of a symbol with other symbols, in what Turner calls a configurational analysis (cf Turner 1967:50-51).

With regard to Ndembu divination, Turner's analysis primarily stresses the levels of positional and exegetical meaning. He states that 'the dominant unit of divination is not the individual symbol, but the symbolic configuration' (1968:39; 1975:225). For his analysis of these symbols' configurational meaning he almost exclusively relies on the esoteric exegetical explanations by some key informants, in particular the Ndembu ritual specialist Muchona. In his analysis of divination, Turner gives far less prominence to the level of operational meaning. ${ }^{3}$

Turner's notion of exegetical meaning presupposes a stable and unproblematic relationship between a symbol and the meaning it conveys: as exemplified by Muchona's accounts, symbols, even if they simultaneously condense multiple meanings, can in principle be 'read' or decoded, verbalized and cognitively grasped. Symbols become substantialised entities. The symbol as thing has a revelatory character. Like a Ndembu blaze-trail (chinjikijilu), it leads from unknown to known, or from the hidden and unpredictable to the concrete and the familiar. Working with such symbols, the Ndembu diviner 'regards his task as the practical one of revealing the causes of misfortune or death' (1968:27; 1975:209). One of the diviner's avowed aims, says Turner, 'is to make known and intelligible in Ndembu terms what is unknown and unintelligible' $(1968: 43 ; 1975: 230)$, or to bring into the open what is hidden or unknown' (1968:29; 1975:211). This aim of exposing and revealing shapes, Turner contends, much of the symbolism of divination (1968:30; 1975:213).

In the 1975 version of his essay on Ndembu divinatory symbolism, Turner situates the structure and the properties of the symbolic objects used in Ndembu basket divination between the symbol-the expression of an unknown fact-and a sign, the 
expression of a known thing (1975:207). In his introduction to the collection of which this essay forms part, he drops the Jungian contrast between symbol and sign, and instead places divination in opposition with revelation. Divination (which discloses what was previously concealed) is described as a mode of analysis and a taxonomic system, while revelation (which is the manifestation of what resists conceptualisation in the linguistic terms available to the Ndembu) is the prehension of experience taken as a whole (1975:15). Although divinatory symbols share many of the properties of the symbols that occur in the context of healing rituals-both aim at -solola, making visible-Turner states that the emotional resonance of their meaning is not as strong, and neither is their fusing of the sensory and ideational poles. They are less synthetical and more analytical than other ritual symbols (1968:44; 1975:232), less highly condensed and with a higher degree of 'brittle segmentation' (1975:232). Their meaning can therefore more easily be interpreted and rendered on a discursive and logocentric level than that of the symbols used in life crisis or healing ritual. Hence Turner's focus on the level of the exegetical meaning of the objects in the divination basket. In his view these objects form a kind of text, a commentary on the facts of social life. They are 'mnemonics, shorthands, cyphers; and each one refers to a whole series of stereotyped ways of thinking about and evaluating Ndembu society and culture' (1975:239). In other words, the configurations or Gestälten of divinatory objects in the divination basket provide a script which can be narrated and explained by the diviner, in order 'to bring into the open the secret, and even unconscious, motives and aims of human actors in some situation of social disturbance'. As such, divination becomes a mechanism of social redress (1968:46; 1975: 236,241 ), and the diviners' role, situated between the judge and the ritual expert, is that of 'upholders of tribal morality and rectifiers of disturbed social relationships' (1968:51; 1975:241-242). 'It is in the light of this function of divination as a mechanism of social redress', says Turner, 'that we must consider its symbolism, the social composition of its consultative sessions, and its procedures of interrogation' (1968:46). A one to one relationship exists between the divination basket and the defined order of the social context which brackets the divinatory séance.

Recent postmodern developments in anthropological writing have increasingly made clear to what extent the assumed fit 
between signifier and signified, between representation and reality, or between knower and known, is problematic (Harvey 1989; Rosaldo 1989; for a brief overview of this evolution see Lutz 1993). In the light of this shift in the understanding of the nature of anthropological interpretation, Turner's own logocentric and reflectionist use of the concepts of symbol and metaphor as leading from the unstructured and the chaotic to the structured and ordered, has recently become the object of much critical scrutiny (cf. Foster 1990; De Boeck 1993b). The latter argues that Turner does analyse the properties of multivocality and unification within single dominant 'key symbols' or 'root metaphors', but that he fails to account for the multi-directionality of symbolic or metaphoric processes, and hence for the essentially open-ended interrelation between symbols or between metaphors. Symbolic configurations, because of this open-ended fractality and unmappability, may even move beyond, and thereby elude, the generation and revelation of meaning. In fact, analyses of the type offered by Turner, even when they are as brilliantly done as Turner's, reduce the emergent creative capacity of the ritual to something else: ritual is not regarded as an autogenerative praxis, and the social order is seen as its hidden script. For Turner, contradiction or conflict are the major source of symbolic production, and conflict management is its major function. Symbolic devices, whether it be in communal rituals or rituals of affliction and redress, mobilize energies, affects, and motives so as to make the social virtues desirable while realigning people in 'social processes of unification', in a communal concern 'with the health of the corporate body, with securing balance and harmony between its parts' (1968:270). We argue, on the contrary, that the cognitive, meaning-centered level in Turner's analysis needs to be balanced by a more praxiological dimension, in which the stress is put on agency, enforcement and worldmaking rather than on structure and social engineering. Instead of viewing divination, for example, solely as a mechanism of social redress, in which the divinatory objects function as 'idiosyncratic features' $(1975: 236)$ of the social framework, attention should be devoted to divination as act rather than fact. In our analysis of divination predominance is therefore given to the performative generation of relations and involvement in the life-world, rather than to the for$\mathrm{mal}$ and narrative representation of a social order, made explicit in the diviner's exegetical comments to the anthropologist. 
Divination among Ndembu

Ndembu basket divination is very similar to the ngoomb ya chisuk(a), the basket divination used by Luunda (cf. De Boeck 1991). Yaka divination does not use the basket technique, though its mediumistic source of knowing, the behaviour of the consultants, and many key etiological dimensions in the oracle are similar to the Luunda case (Devisch 1993: chap. 5). Both the Ndembu and the Luunda forms of basket divination derive from an Angolan divinatory form of Chokwe origin (De Boeck 1993a; Turner 1975:247). This method of divination consists of an open analogical system in which use is made of a varying set of figures (L: atupeel, atupeedi) and substances of animal and vegetable origin (maamp ma ngoomb). These objects constitute the content of the divination basket. They are tossed up (L: -sukul, -sekul, -eehul) by the diviner (L: mwiin kupoong) in changing configurations. ${ }^{5}$ The objects thereby function as expedients for the diviner in his search (L: -soot, -eengul) for the what, the who and the why of the illness, misfortune, or death. ${ }^{6}$ The Luunda verb -eengul refers to the decanting of palmwine to separate the good wine from the sediment. In an analogous way the diviner separates the relevant from the subordinate data in his search for all the ins and outs of the affair which is presented to him. Ndembu use the similar image of winnowing (1975:215). ${ }^{7}$ Like the Ndembu, Luunda and Yaka travel considerable distances in order to consult a diviner. The consulting party usually consists of maternal and paternal representatives of the victim. Most often Luunda consultants are accompanied by an unrelated observer, who will present a summary of the session to the village elders. The suffering person in question is never present at the consultation.

Turner considers Ndembu divination as a means of social engineering. In Schism and Continuity (1957)-his classic on conflict and contention among the Ndembu-Turner introduced the concept of social drama, a concern and perspective which he would redefine and reformulate throughout his œuvre. In the ongoing social drama, Turner has us see Ndembu social structure in action. The social drama consists of a four-phase basic pattern, which leads from a breach in the social relations and the outbreak of a social crisis, via a moment of-legal or ritual-redressive action, to the final resolution of the conflict, either through restoration or the 
recognition of the breach. This model formed the transition from the classic static functionalist explanation of social conflicts to a more dynamic and processual approach to social life seen as performance and staging (for a more extensive description of this evolution see Comaroff and Roberts 1981).

Throughout his career Turner continued to reformulate the model of the social drama, to come to terms with his developing interest for the processual, the symbolic, the cognitive and the performative. In the later formulations of the model the sociopolitical dimension-strongly stressed in Schism and Continuity-remains present, but more and more, symbolic and conceptual, actororiented levels are foregrounded (cf. Turner 1980:152). This goes hand in hand with an increasing stress on the temporal, i.e. processual, as well as the narrative, discursive, interpretive and reflexive aspects of the ritual as microsocial drama (cf Jules-Rosette 1988:148). In one of his later reformulations Turner defined the social drama

'in its full formal development, its full phase structure, as a process of converting particular values and ends distributed over a range of actors into a system (which is always temporary and provisional) of shared consensual meaning' (1980:156).

Turner thus places the narrative in the very center of the social drama, as 'reflexive activity which seeks to "know" (even in its ritual aspect, to have gnosis about) antecedent events and the meaning of those events' (1980:167).

As such, the social drama becomes the 'social ground of many types of narratives' (1980:145). These narrative types are generated in the third phase of the social drama-the phase of redressive action - and they can be of legal or ritual nature. Divination, given its affinities with both the judicial process and with more standardized processes of redressive ritual (1968:25), occupies a central position among the various narrative types generated within the social drama. States Turner:

'Meaning is apprehended by looking back over a temporal process: it is generated in the narrative constructed by lawmen and judges in the process of cross-examination from witnesses' evidence or by diviners from their intuitions into the responses of their clients as framed by their specific hermeneutic techniques. The meaning of every part of the process is assessed by its contribution to the total result.' (1980:157).

In divination, narrative and di'scursive concepts of time are played 
off against one another in order to arrive at a reconstruction of what Turner calls 'temporal structures', that is sequences of social events which are organized by means of relations in time rather than in space (1974:35), and which lead to the moment of crisis. Ndembu, Yaka and Luunda divination actually deals with three time moments. First of all, it is retrospective. The divination deals with a problem in the present by looking at its antecedents. In the Ndembu and Luunda basket divination session, as well as Yaka divination, the diviner sets out on an a posteriori search of the etiological chain of events leading up to the problem, the illness, the death or the instance of misfortune which formed the immediate inducement for consulting the diviner. The reconstitution and hermeneutical interpretation of past events and etiological relations (preceded by a diagnosis of the present situation of the victim) enables the diviner to suggest a future ritual and/or therapeutic solution to the consultants. In the Luunda case, it is often the diviner himself who will act as the healer or the ritual specialist for his client. In that case, the diviner may accompany the consulting party to their village, or-if this is considered better for the patient's well-being, for example in cases of sorcery-the patient may be brought to the village of the diviner. In either case, diviner and patient spend many weeks, sometimes even months, together, in order to bring the therapy to a satisfactory close.

The three time moments dealt with in the divination session (past, present, future) fall together with Turner's use of Dilthey's concepts of Bedeutung, Wert, and Zweck:

'[...] meaning (Bedeutung) arises in memory, in cognition of the past, and is concerned with negotiation about the "fit" between past and present; and value (Wert) inheres in the affective enjoyment of the present, while the category of end (Zweck) or good (Gut) arises from volition, the power of faculty of using the will, which refers to the future.' (Turner 1980:156; 1987:95-96)

As such, the divination session constitutes a crucial moment in the ongoing social process. It is situated in the third phase of the social drama, the phase of redressive action (1968:46-51; 1975:234-242), but it covers the preceding and following phases. The phase of divination, like the third phase as a whole, thus is a liminal phase, a moment of 'liminal reflexivity' (1980:157). As such, Turner states, it 'furnishes a distanced replication and critique of the events leading up to and composing the "crisis"' (1974:41). 
Our Luunda and Yaka data do not support Turner's view that ritual and divination merely serve social engineering. For Turner the outcome of the social drama is surprisingly simple. The final fourth phase 'consists either of the reintegration of the disturbed social group or of the social recognition and legitimization of irreparable schism between the contesting parties [...]' (1974:41). For Turner the final outcome of the social drama is situated in the social field, in a reintegration or restauration of the situation before the crisis, or the officialisation of the rupture (which implies that the redressive action has failed). This view is embedded in Turner's notion of the 'temporal structures' which give form to the social drama: 'the organisational foci of temporal structures are "goals", the objects of action of effort, not "nodes", mere points of diagrammatic insertion or lines of rest' (1974:37). In other words: the ultimate aim, the finality of the social drama-and in particular that of the third phase, of which ritual action, and especially divination, forms a key moment-is to heal a situation of aberration and to work towards a social consensus-through reconciliation or through legitimation of the breach-in order to effectuate a return to the 'normal' social order. Turner, in other words, has great difficulty in considering ritual in its own right. The transformative dynamics, the intentionality and the efficacy of the ritual moment are placed outside this moment: their script is in the social order. The role of the divination process and of the ritual therapeutic action which ensues from the divination moment (and which, as mentioned before, is often undertaken by the diviner himself), is measured by the effect (namely, the reaching of consensus, reintegration or rupture) which it has in the social context that brackets the ritual moment. This is further confirmed by Turner's use of Dilthey's concepts of Zweck and Gut, which situate the effect of the redressive phase in the future and in the social field. The liminal phase of the social drama is thus reduced to subjunctive anti-structure (see also 1969, 1977), and the divination itself becomes nothing but a transformative 'mechanism of social redress' (1968:46; 1975:235).

Underneath the structural argument about the transformation of structural contradictions to more socially acceptable forms, lies the essentially functionalist assumption that harmony, order and con- 
sensus form the norm-ality of Ndembu society (see also Adler and Zempléni 1972:205), and that the ritual moment works towards this norm. Says Turner (1980:165-166): ' $[\ldots]$ the innovative potential of ritual liminality seems to have been circumscribed, even dormant, or pressed into the service of maintaining the existing social order'. The transformation which takes place in the ritual moment is thus viewed in mechanistic terms as a formal, structural change of one set of categories and relations to another. This implies an impoverished view on the dynamics of ritual transformation, which is located in structure and in form rather than in the practice of the ritual performance itself. In his later work, Turner does describe the social drama from a more performative point of view. In these later reformulations social drama is understood as an 'experiential matrix' (1980:158), the narrative becomes 'experiential knowledge' (1980:167), and performance is viewed as an auto-transformative event (1980:160), capable of generating totally new, previously non-existing 'insights' and meanings. However, for ascribing an auto-generative quality to ritual performance, Turner turns towards a religious explanation. He is convinced that symbols may have an innovative load or effect that outreaches their meaning. However, this effect is not generated in and through the ritual performance itself, but is put into the performance by super- or supranatural forces. The performance as such is again reduced to form and structure: it is merely a 'new bottle' (1980:160), made for the new wine, poured into the bottle from above.

Our first point of critique concerns this alleged restaurative function for the group of the divination and the ritual action that issues from it. Among the Luunda and the Yaka, the value of divination and the resulting ritual action cannot be measured by the degree in which an effect-consensus and reintegration or legitimation of the rupture-in the social field is reached. Although it is thrue that the consultation process of divination supports, regulates and reproduces the social system, the essence of what the oracle itself does as a mode of worldmaking cannot be captured by means of an external approach which limits itself to the effects of the divinatory examination on the social level.

The open-ended meaning that comes about in the divinatory oracle is not to be reduced to the policy of the interested parties. Nor is social redress always their aim. Turner focuses on the strategies of the family elders or consulting parties: the divinatory 
consultation is aimed at reconciliation. To support Turner's perspective, it may be noted that the Luunda call the diviner 'the eye of reconciliation' (diis dia nakayuul), a name also given to political title-holders. ${ }^{8}$ The divination itself is directed at taking away, or rather, bringing to the surface, the problem. It is compared to 'an axe which cleaves the trunk of the tree that remained in the ground after the tree was cut down' (that is, after the kin group was hit by misfortune). However, both Luunda and Yaka say that 'even when the divination brings shame, the diviner goes ahead with the ngoomb(-u)'. A diviner is 'shameless', he cuts or slices all problems, whatever the consequences. Therefore he is referred to as 'the needle and the knife'. Divination is a hermeneutic of disclosing, a worldmaking in perpetual emergence, compared to weaving: it posits a world of becoming, withering away and re-emergence, of death, gestation and rebirth. When the Luunda diviner starts shaking his rattle (luzeenz) at the onset of the oracle, he draws out these forces of regeneration and death, and sets the scene for 'the greeting of the ngoomb', a cosmogonic speech in which he evokes the awakening of the world. ${ }^{9}$ Among the Yaka, the final divinatory verdict is seen as 'cutting off' ( $Y$ : -zeenga) the new weave, whatever its social bearing (Devisch 1993: chap. 5). In other words, divination is not necessarily a redressive mechanism. Among both Luunda and Yaka, the outcome of the oracle, and more in particular the identification of the culprit (i.e. the sorcerer or the one who is at the onset of the problem), often exacerbates the crisis. In that sense, divination may make it more difficult to arrive at consensus and to bring the social drama to a satisfactory close. Divinatory consultation may even be used to evade or to serve factional strategies, for example by establishing consensus within a section of the kin group for the sake of dissension in the larger kin group (De Boeck 1991). Although basket and mediumistic divination enjoy the greatest prestige among all the forms of divination available among the Luunda and Yaka respectively, people will often try to postpone the consultation of the diviner, for as likely as not the outcome of the divination session is liable to create further tensions within the consulting group. Often the various interested parties start lobbying in order to postpone a consultation of the diviner or invalidate its outcome by playing it off against another diviner's. It is also common for people not to follow up on the oracle's final outcome. This neglect can in turn lead to a new series 
of insinuations and accusations. Among Luunda and Yaka it also happens that the kin group of the suspected wrongdoer may decide to take the blame for the illness, death or misfortune, without consulting a diviner. The suspected kin group hands over a restitution to the victim or his kin group, the so-called gift that 'wakes up the victim' (L: -laankweesh muntw), or 'compensates for the victim who has been tied in' (Y: -futa bibiindi), and thereby evades a consultation and the disrepute which follows from the oracle's authoritative outcome. In fact, the 'social drama' is seldom brought to a satisfactory close. This does not mean that it leads to an established rupture. Among the Luunda 'endemic, pervasive, smoldering factionalism' $(1974: 41 ; 1987: 35)$ seems to be the rule rather than the exception. ${ }^{10}$

Most of the time the social drama does not lead to a solution, but multiplies into social dramas, in an auto-generating process of conflict and conflict resolving. As such, divination is but a small, although crucial, part in this endless process of conflict management and decision making. Therefore the significance of the third phase, in casu the divination moment, should not be restricted to its outcome, or solely be assessed in terms of the practical, tangible results in the social field only. These are, in a certain way, only subordinate. The significance of the divination session situates itself in the internal ritual process, which is far more encompassing than the propositional and discursive level evidenced by the diviner's 'reading' of the symbolic objects or by his etiological pronouncements sensu strictu.

The cognitive and discursive character of the social drama: A further critique

Our second point of critique bears on the cognitive and discursive character of the social drama, and hence of the way in which Turner views the divinatory moment. For Turner the cognitive aspect is the most important in divinatory symbolism, whereas the orectic, emotive aspect prevails in rites. The symbolism in rituals of affliction is basically synthetical, as opposed to the analytical character of divinatory symbolism (1975:231 ff) - a distinction that becomes less pronounced in Turner's later work.

Again, Turner looks at divination from the perspective of the well-informed and lucid entrepreneur, be it a group or a family elder. His cognitive bias leads him to stress the intentionality and 
goal-oriented character of the divination. The latter aims at the elaboration of a corrective strategy in the social drama and works towards a set of practical therapeutic and moral actions and issues. As such, divinatory symbolism is viewed in the light of its function as a mechanism of social redress.

Contrary to Turner's external and cognitive approach to divination, more recent approaches to divinatory methods and symbolism have turned away from a view of divination as a mere representation of social structure, or as an instrument for social analysis (cf Peek 1991). As Devisch (1985:62) noted:

\footnotetext{
'Focusing on divination as a form of acquiring knowledge for establishing, controlling and predicting order, the cognitive approach offers the epistemological complement of the structuralist-functionalist interpretation of divination. Both approaches take the phenomena at their face value, considering mainly the literal meaning of the consultor's ideas on divination and of the matters dealt with in divination, and also the literal meaning of the context of oracles and divinatory oral tradition.'
}

In Luunda and Yaka divination, and we think it is legitimate to extend our argument to the Ndembu practice as well, the sense and meaning of the divination are not at all restricted to the discursive and cognitive level. Most of the time, for example, Luunda consult diviners of Chokwe or Suku origin, and even when both diviner and consultants are Luunda, the divination will proceed in the Chokwe language, which some of the consultants do not master well (cf De Boeck 1993a). On top of that, the diviner is not totally the author of his own words. Rather, it is the ngoomb(u) who speaks through his mouth, in a rather cryptic, and sometimes very poetic and highly metaphorical, language which is not readily understood by the consultants. This is even more so in urban contexts where consultants of different cultural and linguistic backgrounds come to see the diviner. It is on the level of the performance or divinatory praxis itself that the divinatory moment becomes autopoietic. On this level the ritual of divination may be seen as a 'synthetic' and transformative praxis, which generates its own efficacy in and through the performance itself. The transformation-which includes more than the resolution of the conflict-is not solely situated on a logocentric level, or in terms of psychological and/or social consequences: in the act of performing and doing, the transformation is being embodied by the consultants in the ritual praxis. As we will illustrate in the next section, the performance of 
the oracle brings about a genuine relationship between the consultants themselves and the diviner, while renewing and redefining in a very tangible and concrete form their relations of reciprocity, commensality and solidarity, as well as their involvement with the life-world, which were weakened by the confict. The reflection and sharing of enforcement to which the divination moment invites the consultants, is essentially one through praxis. In that sense the divination performance and the sequential genesis of the etiological diagnosis already carry in themselves the meaningful (re)generation of a new integrative social and world-order.

Sensory and bodily symbolism in Luunda and Yaka initiation of the diviner-to-be

$N g o o m b(u)$ divination demands a high level of ritual knowledge and expertise (L: kujikij). This knowledge is acquired during a long initiation and training period under the guidance of a reputed diviner: in the Luunda view, he acts as 'father' or 'lord of the ngoomb' (L: mwaant wa ngoomb, taatukw a ngoomb); among the Yaka a (male) 'senior-diviner who acts as his mother' (ngula ngaanga) organizes the initiatory seclusion of the diviner-to-be and completes the paraphernalia so as to release his full mediumistic capacity and protect him against sorcerers. A similar relation exists among the Ndembu. Turner (1975:250) notes that the initiation master is referred to in maternal rather than paternal terms. Not everybody can become a diviner, nor does it suffice to acquire the necessary technical skills. The ngoomb $(u)$ chooses the new diviner by manifesting itself to him in a dream: the latter 'resurges' the divinatory capacity (LY: - $\operatorname{hiing}(a)$ ngoomb(u)) of his ancestors. Among both Luunda and Yaka, divinatory skills are transmitted matrilineally. For Luunda and Chokwe (the diviners Turner spoke to were of Chokwe origin), this transmission almost invariably takes place between (classificatory) mother's brother and sister's son. Almost half of Yaka diviners are female: the matrilineal transmission of divinatory skills is through both genders, that is from (classificatory) mother's brother to sister's son or daughter.

Luunda/Chokwe and Yaka initiation into divination is somewhat different. Let us start with a brief description of the Luunda/Chokwe case, then of the Yaka. We intend to point out 
some of the bodily and sensory symbolism in the initiation as well as in the diviner's shrine and ritual objects. It will be shown how this symbolism links in with notions of bodiliness and personhood, social organisation and worldmaking.

Among the Luunda and Yaka, divinership is the outcome of an affliction that is thought to be, in a sense, congenital. It is considered that ngoomb(u) (the nonancestral spirits of the cult of divination transmitted matrilineally), through persecutive illness, causes the transformation in the diviner-to-be. The trance is both a major congenital affliction in the uterine line and a resource for the healing of the initiate and the revivification of her or his life-world.

\section{Luunda initiation}

According to Luunda tradition, the ngoomb manifests itself, through the mediation of a matrilineally related ancestral diviner, to the diviner-to-be in a dream during his illness (-lat ngoomb). Thereupon the candidate leaps into a deep, and sometimes wild and spectacular trance in which he climbs on top of trees or houses. This trance is rendered by several verbs: -kaluk, -puumbuk, -twiik, -vuuk, meaning 'to jump up', 'to start up', 'to fly', 'to leap'.11 During his trance the diviner-to-be takes 'possession of the ngoomb', i.e. acquires the clairvoyant capacities (-baak ngoomb). A senior diviner is called upon to diagnose the nature of the affliction. After an initiation night on a crossroads, or a cleared spot (huung) outside the village, a divination shrine, the so-called chineeng cha ngoomb, is erected at the new diviner's house. From then on, the new diviner can start to carry out oracles, although under the guidance of his initiation master or another accomplished diviner at first. Sometimes, while divining, the diviner lapses into a mild, trance-like state which is reminiscent of his initiatory trance.

Both during the initiation night and during the erection of the chineeng cha ngoomb, the symbolism of chicken and rooster is prominently present.

1) Sequence 1: during the initiation night: After the initiatory trance, the novice is lead to a crossroads outside the village where the initiation night will take place. During this ritual the new diviner will be given his basket. ${ }^{12} \mathrm{He}$ is accompanied by some of his maternal relatives, his senior wife and the initiation master. At the crossroads the maternal representative, or 'mother' of the diviner-to-be gives 
the initiate a cock and a chicken, the so-called 'tribute to the ngoomb' (mulaambw a ngoomb). The blood of the cock is poured into the basket 'to strengthen the ngoomb' (-soonz mash). Part of the hearts of the cock and the chicken is put in the horns and medicine bundles that are integrated into the divination basket. The rest of the cock and the chicken is given to the novice's senior wife. She will prepare the cock on a fire which is lit to the right of the crossroads. The chicken, together with some ritually prepared manioc mush (luku lwa mutuund), is prepared on a fire lit at the left side of the crossroads. The ritually prepared meal is then shared by all present on the crossroads.

The remaining part of the chicken and the rooster are swallowed by the diviner, so that they 'enter into his heart' (-aandam mwi ntul). They make the diviner 'see', and give him munany, namely the capacity that stimulates the novice's gift to 'feel' and 'see' his way into the problem. It stimulates his intuition (chivuvu), marked by the exaltation or the 'leaping up of his heart' (lwaansh). Diviners state that they simultaneously feel the 'seeing' in the heart. Therefore, the initiation not only focuses on the diviner's eyes, through a ritual 'opening of the eyes' (-soonz mees) which involves the application of a preparation containing, among other substances, the eyes of a cock, a pigeon and a chameleon, but the ritual also centers on the diviner's heart or chest. First of all, as indicated above, the initiation master makes the novice swallow the remaining part of the hearts of the chicken and the rooster. Secondly, an incision is made on the diviner's chest, and ritual substances are rubbed into it to increase the munany, the diviner's capacity to forefeel and foresee. These substances include the ashes deriving from the hearts of two kinds of moles, mutwiit (unidentified species of mole) and nkol (mole-rat: Heliophobus robustus). The hearts are burned in the fire on which the cock was prepared. The Chokwe name of the mole mutwiit is munany, which in uchokwe literally means 'forefeeling' or 'foresight'. In uluund the verb -nanik means: (i) to walk like a chameleon or a chief (cf connotation of neengnan), and (ii) to comment upon. Like a chameleon the diviner progresses slowly and cautiously, his eyes turning in every direction. Like a mole he carefully digs his way through the particulars of the problem presented to him. ${ }^{13}$

Last but not least the initiation master prepares a mixture of human, animal and vegetable substances. This preparation is 
called (mu)fiimbu. Part of it will be swallowed by the novice, and the rest will be kept in a small gourd to be re-used during subsequent consultations. The fiimbu heightens the olfactory capacities of the diviner, who is commonly likened to a hunting dog. He smells out the sorcerer like a dog does game. ${ }^{14}$ One of the substances used in the fiimbu is the hearts of twins. Twins, the two that are one, are considered to represent the male and female parts of a being that normally should be one. The first-born is, for example, always associated with the right side, i.e. the side of the father, whereas the second one is associated with the left or maternal side, the side of the heart. As such twins also represent to some extent the male/female duality which one finds in Luunda social structure, and which is symbolised in the use of chicken and rooster (see below).

2) Sequence 2: the erection of the diviner's shrine: Soon after the initiation, the diviner, together with his initiation master, will erect a shrine for his ngoomb. The shrine itself consists of a stick of the muyoomb tree (Amnacardiacae, Lennea welwichii), a tree that is also used for the erection of ancestral shrines. The muyoomb represents the bond or the understanding (kwiyoov) between the diviner and the matrilineal ancestors who chose him to continue their work. To plant the muyoomb stick, the initiation master digs a hole, in which he deposits a chicken's egg and some ritual substances while invoking the ngoomb. The upper part of the muyoomb is carved into a point and kaolin and red earth are applied to this extremity. Sometimes two sticks are planted, representing a male and female part (cf. Bastin 1988b:31). ${ }^{15}$ The initiation master then kills the cock and puts its head on top of the stick. The point of the cock's heart is swallowed by the novice. Later on, when consultants will come to the diviner, the latter will offer them a chicken (see below). Every time the chicken's head will be put on top of the muyoomb. The remainder of the chicken will be prepared by the diviner's senior wife, together with some manioc mush. Part of the manioc will be deposited at the foot of the stick before starting the consultation. The rest of the meal is offered to the consultants.

\section{Yaka initiation}

The ngoombu cult of divination addresses patients suffering from a loss of the senses, involving a state of 'dispersal' ( $n$-luta): they 
intrude other people's private space during hysteric or epileptic-like crises, and may suffer from 'excessive heat or fire', itching, nervousness, or irascibility. Or, on the contrary, they may be in 'a state of contraction, of being tied in' (yibiinda), in which the afflicted is withdrawing from social contact and suffering from respiratory and pulmonary disturbances such as persistent cough, forms of bronchitis, and asthma. Some patients confess how much they feel persecuted by the shade of a deceased diviner relative, feel blocked by extreme anxiety or apathy, and withdraw from social contact. These are in fact all symptoms which may manifest an individual's vocation as mediumistic diviner. When the crisis tips over into a trance state that shows the pattern of ngoombu, the patient may be considered a medium ready for initiation into divinership.

The medium metaphorically integrates the regenerative capacity of the chicken. Entranced, the diviner-initiand may climb to the crest of a palm tree, or jump onto the roof of his house, and then leap to the ridge and tear off the straw. His entire mime (the movement of his eyes, head and body; his prancing about; his walking on the balls of his feet and crowing 'coo, coo, coo') imitates the behavior of a chicken. The possessed medium then reveals the name of a matrilineal forebear who was also a diviner and who now calls a successor. These various aspects of entranced behavior are termed -puumbuka (leap), -kaluka (release, deliver oneself), or -vuula (slip away) (cf Luunda terms above). Such a trance authenticates one's calling to the divinership, and so any relapse reminds of it.

After such an initiatory trance the diviner-to-be is secluded for nine months in a hut which is erected at the edge of the village space. The seclusion aims at healing his affliction. The prescribed ritual behavior, the songs and paraphernalia of the cult, and the support of the group, attune him to the gift of clairvoyance that is awakening in him. During his initiatory seclusion, the novice is likely to enter in a trance every time he hears about, or witnesses, sorcery.

During the coming-out ritual, which takes place at dawn, the medium withdraws to a stretch of wood at the edge of the homestead. There he starts behaving like a predator. In a trance, the diviner bites off the head of a chicken. A close parent carries the diviner, who holds the chicken's head in his mouth, on his shoulders into the village. When they reach the seclusion hut, the diviner, prancing about in a trance-like state, again becomes the brooding hen he identified with during the seclusion. 
The brief description of the sequences of ritual initiation is telling of some of the more important ritual aspects of divination. Within the limits of this article we will highlight only some elements.

\section{Luunda diviner: towards embodying mediation}

Among the Luunda, most of the action during the diviner's initiation aims at an integration of male and female substances, of head and heart, cock and chicken, white and red. Luunda society itself is part of the matrilineal puzzle of the savanna-belt, described at length by Turner and others. Whereas descent is predominantly reckoned along matrilineal lines, residence is patri- or viri-local. The individual is linked through complementary rights and duties to the father's and the mother's maternal lines. From one's father one receives one's social identity, personality and name, passed on through the paternal seminal fluids. The principle of recruitment that determines lineage membership, however, is not, or only in a submerged way, traced through the father's matriline. The muyoomb-tree as a symbol of lineage continuity is said to have been planted and transmitted by the maternal uncle, the 'mother without breasts'. Common ancestry is reckoned through the mother's line, and lineage membership is gained through the mother. Kinsfolk are those born in the same vumw, the same lineage or, literally, 'womb'. It is a woman of the third or fourth ascending generation who represents the lineage's founding ancestor. Within the lineage, this ancestor is represented by the mother's brother. The vumw as lineage/womb is thus, like a female body, a container which conveys the individual's membership in the group.

The individual thus has, in a certain sense, a double sense of belonging, and in his life there are two poles of authority, the father and the maternal uncle, the two 'guardians of the herds', who constitute his sense of well-being and social worth. In fact, life itself is made up out of these two, paternal and maternal, or male and female forces. Life-force (mooy) is neither male nor female, but is both. Mooy is a liminal and thus an integrative, connecting and relational life-force with cohesive powers, uniting social, cosmological and corporeal dimensions, inserting the individual in the ongoing generational succession, and relating it to others of his own generation, to the people with whom he shares a common ascent or residence. The Luunda consider that mooy in its raw or elementary state is passed on and transmitted by the paternal 
semen. But, whereas it is said that 'one's child is from the father', so it is also said that 'the vital flow is of motherhood'. Mooy is thus also a maternal force, situated in the heart, which is 'with the vital flow'. Like the fire is spoken of as the 'heart' of the house, so the fire that, according to the Luunda, is situated in the womb, constitutes the 'heart of life'. Indeed, matrilineal descent is spoken of as the 'fire left by the ancestors', a 'fire that is passed on' from one generation to the next.

The heart, associated with the left side and linked to the liver, constitutes, together with the womb, the core of the female bodyself. The head, on the other hand, highlights male body and personhood. It is in the head that the main body-centered qualities that constitute the personhood of the senior man (namely speaking, listening, seeing and, in the case of the diviner, also smelling) are located. The crowing cock refers both to male speech and to the elder's foresight, for it is the cock who sees the sunrise and announces the awakening of the world in the east, in upstream direction. Upstream, east, high are spatial axes with overtly masculine connotations. Rhetoric ability, the art of masterful speech, is both a privilege of the senior man, as well as a prerogative for the full attainment of his status as elder. This oratorical ability in a man is highly valued and difficult to attain. A man who does not possess the capacity of expressing himself with such verbal fluency, or who, on the other hand, is overtalkative or speaks empty words, is said to be 'with the death in his chest'. It is 'in the heart that things are felt' but it is through the head that reflection and verbalisation takes place. Similarly the (predominantly) male faculty of 'dreaming' or foresight is situated in the head. The responsible elder is a man who dreams a lot in his sleep, and in his dreams he often is informed of coming events. The elder is therefore referred to as the 'big head that sees dreams'.

Diviners state that 'ngoomb comes to the head'. Simultaneously, however, 'the heart jumps up', as did the diviner himself during his initiatory trance. In this way, divinatory symbolism integrates head and heart, male and female, agnatic and uterine tendencies. In divination a reciprocal relation and interaction exists between the heart and the head: what is reflexively conceptualised in the head and then verbally uttered is at the same time also felt in the heart, since 'it is in the heart that all things on earth are seated.' The diviner's 'seeing' is not only the expression of the authoritative 
stare of the elder. His vision also derives from a much more pronounced female source. An uLuund expression captures this perfectly by comparing the ritual opening of the diviner's eyes to female corporeal processes: the initiation makes 'the diviner's eyes menstruate'. Diviners also say that 'the muyoomb tree is an owl'. As stated above, the muyoomb represents the ancestors in the ancestral shrines, and symbolizes (matrilineal) descent. In the saying the diviner compares himself to the muyoomb, which is the most important tree in terms of life-transmission and the continuation of the lineage, in the same way as the owl is the most important bird of sorcery. Like the owl sees at night, the diviner/tree sees during the day. The association with the muyoomb relates the diviner to his ancestors, and thereby to the matrilineal source of life flow. In fact, the planting of the muyoomb during the erection of the divination shrine is in itself an act of making or regenerating life. The expression 'planting the muyoomb' is commonly used as an euphemism for sexual intercourse or 'the lifting of the leg' (-saangun). The verb saangun is also applied to the diviner's lifting up of the divination basket, as well as to the raising of the luzeenz rattle when addressing the ngoomb (for the regenerative connotations of -zeenz see note 9). In this sense, the act of divining as the awakening of a regenerative flow, is cast in strongly sensory and bodily terms of copulation and orgasm. In fact, the relationship itself between the diviner and his basket is performatively cast in strongly sexual terms: the diviner is to the basket as a husband to his wife. Before starting to divine, for example, the diviner will pass the basket between his legs (silweesh ngoomb) as if it were a female body and womb, rendered pregnant with meaning by the diviner.

The diviner, like the healer, is considered to be with 'life-force and plentitude'. He is the carrier of mooy. In his body-and by means of the mediating object of the basket as female body-he integrates opposing but complementary tendencies, and thereby achieves a bridging function. The vital life-flow itself is a boundless, all-embracing force that generates energy and life through its encompassing and bridging capacity. As such, it has a liminal and generative potential through which male and female body and self are outlined in their corporeal boundedness, and at the same time merged into one another. Equally related through mooy are the father's and mother's matriline, and the alternate generations of ascendants and descendants. Like the vital life-flow the diviner 
encompasses both male and female principles. Hence, for example, the inclusion of the twins' hearts in the divinatory apparatus.

\section{Yaka diviner: a mediator of re-origination}

The initiatory seclusion of the Yaka diviner brings about a 'rebirth' or metamorphosis of the novice and his life-world precisely through a trespassing of boundaries and a metaphoric, or better, metamorphic bridging between polar opposites, such as deathagony and delivery, being born and giving birth. The diviner's embodiment of the source of initiatory transformation is most prominent in the trance.

The Yaka combine patrilineal descent of social attributes with matrilineal filiation. It is believed that physical and innate characteristics, such as health, blood, and inborn capacities (yibutukulu), are passed on to the individual primarily through maternity and the uterine line. These attributes originate from a source of life conventionally associated with the individual's matrilateral great-greatgrandmother. The concern of divination must be placed in the context of kinship and particularly in that of uterine relations. Jurisdiction in councils of elders-on matters of social role and privileges, or political power passed along agnatic ties-draws on societal rules spelled out in proverbs and sayings. Divination, on the other hand, implies an etiological grid that basically relates to uterine lifetransmission. Divinatory oracles are usually given great credence: a diviner acts as a highly respected, public and independent consultant who authoritatively identifies the problem and then directs the sufferer or an afflicted party to the relevant family intervention and, when applicable, to a healing cult.

In Yaka divination and divinatory initiation, the cock, as well as the hen-about-to-lay-an-egg and also the brooding hen, are core symbols. The brooding hen, and to a lesser degree the cock crowing at sunrise, are considered as creatures of transition that crosscut spatial and temporal divisions: cock and hen are the first to be active in the morning, they move between bush and village, and between low and high, pecking around in all the houses and their yards, without making any distinctions. As two-legged domestic creatures, they form an optimal symbolic substitute for the human being in mutation. The brooding hen acts as a symbol of intermediation between the one who engenders and the one who is engendered. By singing at dawn like the cock, the diviner-medium 
announces the end of the realm of the night and of sorcery. By becoming a predator and biting off the head of a chicken, he propitiates the spirit of the uterine forebear-diviner who made him ill. In this way the spirit's aggression to which the diviner-patient fell a victim is transferred to the animal. This transfer allows the spirit to release its capacity for sustaining the diviner's mediumistic art. From that moment on, the medium identifies more fully with the symbolism of mutation and re-origination, in a metaphorical enactment of the brooding hen. The house where the diviner-to-be undergoes the initiatory seclusion is itself like an egg shell which envelopes the initiate. It stands for ngoongu, the primal, egg-like womb of the world. Being secluded inside this 'egg', the initiate is himself engaged in a process of incubation leading towards a new identity.

The novice or diviner-to-be ends his initiation into clairvoyant mediumship in a state of trance in which he metaphorically embodies the behavior of the water shrew (lutsokutsoku). Both the novice and the old diviner-initiator are wearing the skin of the water shrew on their head. This small mammal catches fish and eats insects. Its hole has a double entrance, one under water, the other above. A keen sense of smell makes the water shrew a good hunter. In his trance the novice identifies with this animal: with his bare hands, he digs a tunnel under the ground and crawls through it, to emerge at the other side. In this way the entranced diviner goes through the motions of mortal agony and rebirth.

The trance is a corporeal dramatization of mutation in which the diviner transcends all the demarcations upon which the Yaka worldview depends (cf Bourdieu 1980:348): the trance establishes the order of the demarcations by transcending them in a decisive way. Trance thus permits the diviner to become himself the measure of both norm and deviance. Trance, mortal agony, orgasm, and birth are all symbolically associated, in that they constitute either limit-experiences or the trespassing of human limits, and therefore offer a model of re-origination and self-healing which integrates the corporeal and the sociocultural.

Sensory and bodily symbolism in Luunda and Yaka divination

Divination emerges from dreamwork, keen sense of smell, and transitional modes of involvement with, and thinking about the nature and sources of good and ill health, kin solidarity and its 
perversion. It is our thesis that the bodily enactment in trance and in (mediumistic) divining is both source and product, or agent and scene of interrelating fields of senses, vision and passion, transformed in the same process. These poetics of attuning to one another various domains or fields, which are otherwise kept separate by representational thought or convention, have a transformative, yet integrative, capacity.

\section{Luunda}

Like the vital flow of life, the diviner is 'without boundaries' and therefore capable of mediation and metamorphic bridging between male and female poles as well as between the world of the living, and the underworld (kaluung) where the dead wander. The diviner is the 'one who leads the dead through the bush'. The ngoomb, it is said, 'penetrates the earth' and leads those who come to consult him into the world of the ancestors. Bridging between life and death the diviner is like a 'big talking drum' ( $k u v u$ ). The ancestors speak through his mouth to the living. Being boundless, the diviner has access to both worlds: 'he crosses the river [of life and death] in a canoe, the ngoomb in front'. In the actual consultation, the diviner also interlinks the world of the bush and of the village. Seated 'in the middle of the bush' and at the margins of Luunda society, the diviner comments on the heart of what is the matter in Luunda community.

As such the divinatory séance provides a platform where different oppositions are symbolically and performatively integrated. Hence huung, the name of the ritual space where the diviner is initiated. Like kaluung, underworld, the word huung etymologically relates to a pool of forms such as -nuung, -luung, -ruung that derive from the proto-bantu form *-dungu, which has the connotation of 'to unite', 'to knot', 'to connect', 'to intertwine' or 'to tie' (cf. Faik-Nzuji 1992:47 ff). The huung or initiation ground forms the space where the tying is realised in the diviner's body through the interlinking of the various masculine and feminine-oriented sensory capacities of the diviner. The notion of muhuung $(u)$ is synonymous with munany, the sense of seeing through feeling in the heart. Furthermore the verb -huung is used to denote the accrued olfactory capacity of smelling (fiimbu) that is so characteristic of the diviner and that is stimulated, among other things, through the incorpora- 
tion of the twins' hearts in the divinatory apparatus (see above). By incorporating the two hearts in the divination basket together, the opposite elements are presented as a complementary and unified whole. As represented by the male and the female stick in the divination shrine, the ngoomb itself shares with the twins the essence of dual unity.

While addressing the ngoomb before starting the actual consultation, some diviners comment upon the importance of the male/female unity and the double roots of their art. One diviner stated: 'you ngoomb, you have made us through the mother. The mother goes to the father, by eating from the women, we also eat from the man' [which translates as: I inherited my art from my mother's side. We join heart and head, feeling and verbalisation. Through a ritual meal we join masculine and feminine capacities, chicken and rooster, prepared on the fire to the left and the right of the crossroads].

Most of the meaning of divinatory symbolism, however, is never discursively formulated on a logocentric level, not even by the diviners themselves. Rather, the impact of divinatory ritual is situated for the larger part in the ritual praxis and performance itself. Being seated 'in the middle of the bush', the diviner is rooted like a muyoomb tree on a fixed spot. Like the elder or the title-holder, who forms the middle of the relationships that are being 'knotted' around him, the diviner is the constituting focal point or nexus through which words are passed around. For the Luunda, speaking is considered an act of weaving: it implies colloquy and interaction, and engages the speaker in a reciprocal relationship. Conversations or palavers usually converge around a central elder, who forms the centre to which the 'word is returned' after each intervention. In this way conversation or speech moves on in a circular way, each time returning to a central point, the elder who bridges between the interlocutors and interconnects their words. Spatially, the divinatory seance proceeds in the same way, with the diviner in the middle and the consultants seated around him in a demi-circle. Being the central point, the diviner bridges between the words of the consultants and the words of the ancestors speaking through his mouth. He also bridges between the proposals of the consultants. Their conflicting interpretations of the events that lead to the illness, death or conflict, are mediated and interrelated through the diviner. At the same time the latter weaves or 'forges' the con- 
sultants' propositions into a whole. Whereas in practice his final interpretation of the events may lead to more conflict, on a performative and symbolic level his presence reaffirms reciprocal relationships, expressed through images of commensality. Hence, Luunda will say that they 'eat the manioc mush of the ngoomb together', i.e. that they share food and mutually 'open up their bodies' as a basic sign of trust in each other, to denote the fact that all parties involved go to consult the diviner together. The composition of the delegation which 'carries the problem to the diviner' symbolically gives form to the formal bonds of solidarity that exist between lineage members. The consulting party will include both accuser and accused, maternal and paternal representatives of the victim. Both sides will also contribute to constitute the chikodi or poong, the remuneration of the diviner. Therefore the consultants are compared to termites. As termites work together to build a termitary, so both sides of the kingroup work together to fight the problem.

Ties of reciprocity are also woven between the diviner and his clients. This is done in a very immediate and practical way, for example through the mutual exchange of gifts. Not only will the consultants present gifts to the diviner both before, during and after the consultation, but the diviner will return the gifts in a movement of reciprocity. Shortly after the arrival of the consulting party, the diviner presents a chicken to the consultants (cf sequence 2). The chicken is prepared by the diviner's senior wife and then offered to the consultants, while the chicken's head is put on the stick in the divination shrine. The gift itself is referred to as nzool wa chijimu. The term mijimu denotes physical pain, and the same word is applied to the herbal preparation used by a therapist to ease the pain. In analogy, the diviner's opening gift of the 'chicken of pain' will make it possible to relieve the 'pain', or the conflict, and restore the kingroup's feeling of solidarity, at least on a symbolic and ritual performative level. After the consultation, the diviner will offer a goat (again referred to as a 'goat of pain') to the consultants. The latter will kill and eat the goat and in turn offer the goat's head to the diviner. The gifts 'cause to prepare a meal' (-iisikish), i.e. they establish a relation of reciprocity and solidarity between the diviner and his clients which is similar to the reciprocity that exists among family members. By offering a meal to the consultants the diviner incorporates them into his household, for, as Luunda say, 'it is only 
those that are born together that share a meal with one another.' For the whole duration of their stay in the diviner's village, the consulting party will be housed and fed by the diviner. The morning after the consultation a last ritual meal is again shared between the diviner and his clients. The meal consists of a little bird, shot by the diviner himself. ${ }^{16}$ This bird will usually be roasted by the diviner's wife; a little piece of it will be eaten by all the consultants.

The reciprocal gifts establish a relationship between the diviner and his clients which is similar to that between a maternal uncle and his sister's children. Among Luunda, this relationship is one of the most vital, for the avunculate represents the uterine location of the vital life-force, mooy, and 'plants the muyoomb tree', i.e. ensures the transmission of life between ascendants and descendants within the lineage. The maternal uncle may therefore be referred to as 'the guardian of the muyoomb', or as nkuundj, the house's central forked stick that supports the roof. The same name is given to the small, black termitary (budj) which is used in many ritual and healing practices. Within a ritual context the termitary is considered as the foundation of female fertility, because 'there are so many termites in a termite-nest that one cannot count them'. (The image also echoes the name of termites which is given to the consultants. Working together like termites they enable the termitary, i.e. the diviner, who also identifies himself with the muyoomb tree, to apply his art). The maternal uncle both mediates and differentiates between masculinity and femininity. On the one hand he represents male gerontocratic authority in his role of lineage elder. On the other hand, in his capacity of 'male mother' or 'mother without breasts', he is also identified with female nurturing and generating powers. The diviner shares to some extent with the maternal uncle these dual identities and roles. In many respects the diviner is likened to the political titleholder, the senior elder or the judge, and thus to notions of elderhood, authority, control, speech, the public domain. This aspect is also covered by the image of the muyoomb tree, which is closely linked to the concepts of elderhood and political power. ${ }^{17}$ Like his Yaka counterpart, on the other hand, the Luunda diviner stands in an almost maternal relationship towards his client, through the sharing of food and gifts, and by means of the basket itself as mediating maternal body. The dual role and the double male/female identity of the diviner is again elaborated in terms of the chicken/rooster metaphor. It is said of the 
diviner that he is like a rooster (judge) to sorcerers, but like a mother chicken to his clients.

\section{Yaka}

The Yaka diviner relies very much on his keen sense of smell, and on his heart 'which sees the dreamlike images' (-mona mundosi): the diviner's smell and heart are the seat of his sensory and intuitive or clairvoyant power. Smell or olfactory exchange is a genuine means of intertwining persons, realms, and states, and evokes both repulsion and attraction, processes of decay or death, and of coital life-transmission. The diviner is said to trace the problem submitted to the oracle by his keen sense of smell (fiimbu), which is also characteristic of the water shrew and of the hunting dog. Like the Luunda, people compare the clairvoyant diviner to a hunting dog, tracking down sorcerers and 'smelling out' their nocturnal plots. A hunting dog's skull is ritually prepared to strengthen and protect the clairvoyant's sense of detection. The diviner sniffs at the hunting dog's skull to track the problem, to protect himself, to cross corporeal barriers and spatial limits. Smell, like sexual appetite, is a manifestation of the vital flow (mooyl) (Devisch 1993: 135-136). Upon arriving in the diviner's village, and after a formal exchange of greetings in which the reason of the visit is not revealed, the most senior among the consultants gives the diviner a yiteendi, 'a piece of cloth'-often substituted by a coin-, which has absorbed the client's shadow or double for having been rubbed over his chest. The yiteendi constitutes a kind of intermediary object between the client, the consultants, and the diviner, and establishes the relationship necessary for the oracle to take place. During the entire meeting, the consultants avoid offering any information to the diviner: by their discretion and evasiveness, they seek to test the clairvoyant or paranormal nature of the oracle.

The oracle is born as vision in dream, sleep, clairvoyance through the divining 'eye' (symbolised by the evocative vaginal shape of a cowry shell that the diviner wears on his forehead), and voiced from the diviner's belly. Clairvoyant, mediumistic divination most clearly displays the bodily symbolism of heart and womb: it draws on the oneiric vision in the heart, and voices the life-bearing message of the womb (Devisch 1993: chap. 4). A narrow cylindrical wooden slit-gong, with a carved human head on top and a stick 
inserted into the slit, is commissioned from a local carver and transmitted to the novice at the onset of seclusion (Bourgeois 1983). It is considered to be 'the very image' (yidiimbu) of the diviner. Its womb- and phalliclike shape metaphorically gives form to his capacity to self-generate his new condition and to communicate or bring forth new meaning in a subverbal, bodily, manner. As a modified miniature version of the heavy message slit-gong, it symbolizes the diviner's role as a message bearer to all people.

It is in his belly (yivumu: one and the same term for belly and womb) that the diviner appears as androgynous agent and locus, as the metaphorising author of the uterine flow of life, and as the scene of a rebirth of meaning. Like the shaking of the luzeenz rattle by the Luunda diviner, the 'rhythmical beating of the oracle' (-ta ngoombu) initiates the divination session, and voices the resonance between body, group and life-world. The diviner pretends that whatever message he brings out in the oracle, is being initiated by the rhythm of the slit-gong. Its rhythm is that of the mysteries and spasms of life-transmission through orgasmic sexual communion and delivery, in tune with the cyclical rhythms in the life-world. The oracle is the voice of the selfreliant matrilineal or uterine life-flow from which the individual taps in both good and ill health. Divining recalls the public how much the uterine flow of life is a maturational process that escapes full agnatic and patriarchal dominion: life's inner and passionate impetus from the uterine life source vitalises the social weave that extends through the successive generations of uterine filiation.

The consulting parties have faith in the diviner's message to the extent that its truly clairvoyant or divinatory quality manifests itself. The diviner must be able to identify independently the problem that is 'placed before the oracle'; in the high-pitched voice and accelerated breathing typical of the chanting idiom of his cult, he has to be able to answer himself the fixed set of questions that he is singing out. Gradually overtaken by his inner vision, and as if in a dream, he moves into a kind of trance-like state of expanded consciousness, in which he traces the reason of his clients' consultation and indicates the cause of the misfortune they are facing. The shock of unmasking a sorcery plot may throw young diviners again into the trance behavior that marked their initiation. Afterwards, in a calmer mood and in a more colloquial speech, the diviner further elaborates upon these revelations by means of an analysis of 
the illness based on the etiological grid provided by his cult tradition (cf. Devisch 1991, 1993:169 ff.).

Seen in its own terms, divining is a birthing process rather than an arbitrament, an anamnesis rather than a diagnosis, and a hermeneutics rather than a causal or moral inquiry into disorders. Divination deals with the source rather than the cause of events; it is concerned with the consensual moral order, with the interplay between good and ill health, the strategies in the group, and the lifeworld. Regardless of the actual outcome in the social field, which may well lead to a new chain of accusations and conflict, the way in which the divination session unfolds and the ritual relationships between consultants, or between consultants and diviner, are given shape, places all participants in symbolically renewed and redefined relations of reciprocity, commensality and solidarity. Relations, in other words, which were troubled by the conflict and to which a new content is given in the ritual praxis. This content is interactionally generated within the performance reality as a synthetic and transformative praxis. In this sense Luunda or Ndembu basket divination, as well as Yaka mediumistic divination, are far more than a mimetic reflection of the social structure, or 'a reflexive action which seeks to know the meaning of antecedent events', to use the terms of Turner's social drama model. Divination performatively generates relationships between bodies, people and the cosmos which cannot be fully captured by discursive, representational and cognitive levels of interpretation. In this sense the divinatory praxis and the sequential genesis of the particular anamnesis in the divinatory séance bring forth in a highly corporeal and sensory way the meaningful creation of a new integrative order which interlinks body-self, social body and cosmos. This new order is already symbolically presented in the chicken's egg, an iconic image of cosmic regeneration, which the Luunda initiation master puts under the divinatory shrine (see Lunda initiation sequence 2), or which is at the core of the symbolism that the Yaka diviner embodies.

\section{Conclusion: Disclosing the emergences of forces and meaning}

Trance initiation and the divinatory oracle, practised in the margins of established social life, develop very much as an integral 
system at the transition between the senses, forces of desire, empowerment, and meaning. The main focus is on fields of events and forces in the process of becoming, and on the generation of relations and their intertwinement in and between these fields. Considered in itself, divination is a hermeneutic of disclosing a lifebearing or worldmaking. It posits a world of becoming, of withering away and re-emergence; of flux, rotting and fermentation; of death and gestation; of libidinal forces, senses, and intelligibility, arising from a chaos of potentialities. Divination is a creative process; it is autopoiesis, developing from within, and according to the complex dynamics in which agony and birth, dying and delivery, maternal and paternal, female and male, parent and child, before and after, heart and head intertwine. It brings to the fore, and emerges out of, a resonance between morphogenetic fields in emergence: the maternal womb of the group, the womb of the world.

Our method of analysis entails the parallel investigation of various fields, that is of the multilayered weave in and between the fields of body, group and life-world. The analysis is 'internal' inasmuch as it discloses the autopoietic process and the morphogenetic method of initiatory transformation from within, taking into account divination's own devices, perspectives and intentions. As such, the analysis takes into account the reverberation between the fields of the body, the family or group (initiator - initiand, diviner - consultants), and the life-world. In this approach, divination is not merely viewed as a redressive action, nor is it seen as a narrative that cognitively links up past and present. Rather, it is understood as a self-generative practice, of which the most readily observable aspect is the sensory. As a drama establishing a transitional space, and transitional modes of thinking, sensing, feeling, divination is not concerned with the imposition of reason or truth upon facts of misfortune, or with the presentation of a readable or representable order of these facts. The performing subject is not the initiator, the initiand, the spirit, the diviner, the consultants, or the group. The subject is the (re)generative process of intertwinement between the vital flow or life-force mooy(i), the senses, the body and the world about. The subject is, in other words, the method or art of divining: the multilayered weave in and between the fields of body-self, group and life-world, profoundly linked in an interactional drama, and emerging-like the diviner-water shrewfrom the womb of the world. 


\section{NOTES}

1. The Luunda data presented here derive from De Boeck's anthropological field research (1987-1989 and 1991) among the Luunda of the Nzofu territory, which borders on the Angolan province of Lunda Norte, and which is part of the administrative unit of Kahemba, in the Upper-Kwaango, some $1200 \mathrm{kms}$ southeast of Kinshasa. The data on divination are based on long contacts with six diviners. Some thirty oracles were recorded and annotated. Research was financed by the Belgian National Fund for Scientific Research and the Research Fund of the Catholic University Leuven.

Devisch draws on his anthropological research (1972-74) conducted in the Taanda territory, about $450 \mathrm{kms}$ southeast of Kinshasa. His data on divination stem from involvement with eleven diviners; more than two hundred oracles were noted in detail. On two occasions he witnessed the trance and subsequent seclusion of a diviner-to-be. The data he gathered confirm in detail the observations of Huber (1965) and of Father De Beir (1975:31-33, 111-138), who observed divinatory practices in the regional chiefdom of $\mathrm{N}$-nene (Taanda territory) between 1938 and 1945. His annual sojourns, since 1986, of seven weeks among the Yaka of Kinshasa, allow him to say that the divination protocol tends to become simpler in town: divination is also requested by many non-Yaka clients for problems that are related to cash economy, urban jobs, school education, sexual success. Divinatory oracles and the initiation of the diviner are documented in a film (Dumon and Devisch 1992). The research among rural and urban Yaka has been financed by the Belgian National Fund for Scientific Research.

2. See alsa Devisch's evaluation of Turner's approach to two Ndembu cults concerned with female reproduction, namely the nkula affliction cult and the nkang'a puberty ritual (Devisch 1993: 33-37, 245-254).

3. Apart from the fact that Turner seems to view divinatory symbolism as somewhat different from the symbolism in life-crisis rituals or rituals of affliction (see below), the lack of an analysis on the operational level may perhaps be explained by the fact that Turner himself never attended a divinatory séance (Turner 1975:243; Werbner 1972).

4. In a later version (1975:235) it becomes the 'cybernetic' function.

5. For a more detailed description of the composition of the Ndembu, Luunda and Chokwe divination baskets see also Bastin 1959, 1988a; Cordemans n.d.: 157 162; Delachaux 1946; Hauenstein 1961; Rodrigues de Areia 1985; White 1948).

6. Luunda themselves make a distinction between the 'oracle of illnesses' (ngoomb ya mayeej) and the 'oracle of death' (ngoomb ya kufw, ngoomb ya mutuundu).

7. In this respect it may be pointed out that Turner states that the diviners among the Ndembu use a winnowing basket to work with. Both Ndembu and Luunda use the same word, lwalu (Ndembu) or lwaalv (Luunda), to denote the winnowing basket, which is rather big and flat. However, the diviners' baskets among both Ndembu and Luunda, are of a completely different type. Turner himself shows a basket of this type in the photograph of an Angolan diviner (1975:287). Baskets of this type are never used for winnowing, nor are they called lwaalw. In uluund these baskets are referred to as chiin kudiimb, 'that which make falsehood or lies flee'. It may consequently be questioned whether the 'winnowing' image for divination as 'the sifting of truth from falsehood' (Turner 1975:215) is applied by the Ndembu themselves, or derives from Turner's own mistaken identification of the divination basket as a winnowing basket.

8. The Luunda verb -yuul means 'to reconcile'. At the end of the divination session the diviner brings together all the suggestions and offers a summary or a synthesis of the whole session, in order to arrive at a conclusion and to communicate 
in clear terms the 'sign of the divination basket' (chidiimb cha ngoomb), the explanation and the meaning of what he divined, to the consultants. This 'bringing together' or 'interpreting' (-luumbik) of the divination is also referred to as -yuul.

9. The luzeenz rattle contains the seeds of the fruit of the mwiinzeenz tree (Acacia polyanthaca). In ritual contexts the term chizeenz refers to a nest of red ants, which signifies the source of feminine regenerative powers, but also refers to the place of death, kaluung.

10. In his later work Turner himself recognised the possibility of the existence of alternative types and processual structures alongside the social drama (see for example 1980: 151-152).

11. As will be described below, Yaka associate this behaviour with that of a chicken. The Luunda never made a direct comparison between the behaviour of the novice and that of a chicken.

12. As a start, he may be given a basket that belonged to his initiation master, or a new basket may be composed (-paamp, -loong ngoomb: literally 'to hammer' or 'to put in line' the divinatory apparatus).

13. The connotations of -nanik run parallel to those of -neeng (as in chineeng, the diviner's shrine). Neeng means 'intense', 'fixed', as in -tal neeng, 'to look at intensely, fixedly'. -neengnan means 'to walk attentively': the diviner proceeds slowly and attentively, and 'walks' carefully through all the particulars of the case.

14. One of the substances used for the composition of the divination basket is grass from the place where a dog died. The hunting dog is commonly referred to as the 'elder' (mukuluump) of the diviner.

15. The female part will be of the wood musaal (Caesalpiniaceae, Dialium Englerianum), a wood with strong feminine symbolic connotations. Around the stick(s) a ritual fence is erected.

16. The gunpowder used for the hunting of the bird was brought by the consultants and was first put in contact with the patient's body; a successful hunting confirms the outcome of the divination.

17. The muyoomb tree will be planted in front of the house of the senior village elder or the political title-holder, when a new village is constructed, or during investiture. The health and life of the tree is indicative of the elder's authority and wisdom, and thus of the health of the village as a whole.

\section{REFERENCES}

Adler, A \& A. Zempléni.

1972 Le bâton de l'aveugle. Divination, maladie et pouvoir chez les Moundang du Tchad. Paris: Hermann.

Ashley, K. M. (ed)

1990 Victor Turner and the Construction of Cultural Criticism. Between Literature Bastin, M.-L. and Anthropology. Bloomington: Indiana University Press.

1959 'Ngombo, Notes sur des instruments de divination employés dans le district de la Lunda en Angola'. Congo-Tervuren 5: 100-106.

1988a 'A propos du panier divinatoire Tshokwe'. Arts d'Afrique Noire 68: 19-27.

1988b Entités spirituelles des Tshokwe (Angola). Milano: Stampa Sipiel.

Bourdieu, P.

1980 Le sens pratique. Paris: Minuit. 
Bourgeois, A.

1983 Mukoko Ngoombu: Divination Paraphernalia of the Yaka. African Arts 15: $56-59,80$.

Clifford, J.

1988 The Predicament of Culture. Twentieth-century Ethnography, Literature, and Art. Cambridge, Mass.: Harvard University Press.

Comaroff, J. L. \& S. A. Roberts

1981 Rules and Processes. The Cultural Logic of Dispute in an African Context. Chicago: The University of Chicago Press.

Cordemans, E. L.

n.d. Quelques notes ethnographiques sur les indigènes habitant la région de Kulindzi,

De Beir, L. territoire Kahemba. Unpublished manuscript.

1975 Religion et magie des Bayaka. St. Augustin-Bonn: Anthropos.

De Boeck, F.

1991 'Therapeutic Efficacy and Consensus among the aLuund of Southwestern Zaire'. Africa 61: 159-185.

1993a 'Healing from the Margin: Symbolic and Diachronic Study of Intercultural Therapeutic and Divinatory Roles among aLuund and Chokwe'. In Ethnicity in Africa, eds. W. van Binsbergen \& K. Schilder. (Afrika Focus 9).

1993b 'Of Trees and Kings: Politics and Metaphor among the Aluund of Deflem, M. Zaire'. American Ethnologist. In Press.

1991 'Ritual, Anti-structure, and Religion: A Discussion of Victor Turner's Processual Symbolic Analysis'. Journal for the Scientific Study of Religion 30: 1-25.

Delachaux, Th.

1946 'Méthodes et instruments de divination en Angola'. Acta Tropica 3: 41-

Devisch, $\mathrm{R}$. $72 ; 138-147$.

1985 'Perspectives on Divination in Contemporary Sub-Saharan Africa'. In Theoretical Explorations in African Religion, eds W. van Binsbergen \& M. Schoffeleers. London: Kegan Paul.

1991 'Mediumistic Divination among the Northern Yaka of Zaire'. In African Divination Systems, ed. M. Peek. Bloomington: Indiana University Press.

1993 Weaving the Threads of Life. The Khita Gyn-Eco-Logical Healing Cult Among the Yaka. Chicago: The University of Chicago Press.

Dumon, D. \& R. Devisch

1992 The Oracle of Maama Tseembu: Divination and healing among the Yaka of Southwestern Zaire, $50 \mathrm{~min}$. film and video in Dutch, English, French and German versions, Belgian-Flemish radio and television, Science division.

Faïk-Nzuji Madiya, C.

1992 Symboles graphiques en Afrique noire. Paris: Karthala.

Foster, S. W.

1990 'Symbolism and the Problematics of Postmodern Representation'. In Victor Turner and the Construction of Cultural Criticism. Between Literature and Anthropology, ed. K. M. Ashley. Bloomington: Indiana University Press.

Harvey, D.

1989 The Condition of Postmodernity. Cambridge, Mass.: Blackwell. 
Hauenstein, A.

1961 'La corbeille aux osselets divinatoires des Tchokwe (Angola)'. Anthropos 56: 114-157.

Huber, $\mathrm{H}$.

1956 'Magical Statuettes and their Accessories among the Eastern Bayaka and their Neighbours'. Anthropos 51: 265-90.

Jules-Rosette, B.

1988 'Prophetic Performances: Apostolic Prophecy as Social Drama'. The Dream Review 32: 140-159.

Lutz, C.

1993 'Social Contexts of Postmodern Cultural Analysis'. In Postmodern Contentions, Epochs, Politics, Space, eds. John Paul Jones III, Wolfgang Natter \& Theodore R. Schatzki, New York: The Guilford Press.

Moore, R. L. \& F. E. Reynolds (eds.)

1984 Anthropology and the Study of Religion. Chicago: Center for the Scientific Study of Religion.

Peek, P. M. (ed.)

1991 African Divination Systems: Ways of Knowing. Bloomington: Indiana University Press.

Rodriguez de Areira, M. L.

1985 Les symboles divinatoires. Analyse socio-culturelle d'une technique de divination des Cokwe de l'Angola (ngombo ya cisuka). Coimbra: Universidade de Coimbra.

Rosaldo, R.

1989 Culture and Truth. The Remaking of Social Analysis. Boston: Beacon Press.

Turner, V. W.

1957 Schism and Continuity in an African Society: A Study of Ndembu village life. Manchester: Manchester University Press.

1961 Ndembu Divination. Its Symbolism and Techniques. Manchester: Manchester University Press. The Rhodes-Livingstone Papers 31.

1967 The Forest of Symbols. Aspects of Ndembu Ritual. Ithaca: Cornell University Press.

1968 The Drums of Affliction: A Study of Religious Processes among the Ndembu. Oxford: Clarendon Press.

1974 Dramas, Fields and Metaphors. Ithaca: Cornell University Press.

1977 'Variations on a Theme of Liminality'. In Secular Ritual, eds. S. F. Moore \& B. G. Myerhoff. Assen/Amsterdam: Van Gorcum.

1980 'Social Dramas and Stories about Them'. Critical Analysis 7: 141-68.

1987 The Anthropology of Performance. New York: PAJ Publications.

Werbner, R. P.

1972 'Sin, Blame and Ritual Mediation'. In The Allocation of Responsibility, ed. M. Gluckman. Manchester: Manchester University Press.

White, C. M. N.

1948 'Witchcraft Divination and Magic among the Balovale Tribes'. Africa 28: 81-104. 